\title{
Aneurysmal bone cyst of the rib
}

\author{
SABARATNAM SABANATHAN, KLAUS CHEN, CHARLES S ROBERTSON, \\ FAYEK D SALAMA
}

From the Department of Thoracic Surgery and Histopathology, City Hospital, Nottingham

ABSTRACT Aneurysmal bone cysts are uncommon lesions, especially in the ribs. Four patients with aneurysmal bone cysts of the rib are presented and previously reported cases reviewed. A brief discussion of the clinical manifestations, pathology, aetiology, and current treatment of aneurysmal bone cyst is also included.

Aneurysmal bone cyst was first described as a distinct clinicopathological entity by Jaffe and Lichtenstein in $1942 . .^{\prime}$ The term aneurysmal was used to denote the "blowout" radiographic appearance, which resembles the saccular protrusion of the walls of an aneurysm, and also because cystic blood filled spaces are encountered at operation. The name has been generally accepted, though the lesion is neither an aneurysm nor a bone cyst. The cyst is a relatively rare non-neoplastic lesion, accounting for only 26 cases $(1.3 \%)$ of 2000 primary bone tumours at the Mayo clinic. ${ }^{2}$ Most lesions occur in the spine and long bones, with few in the ribs. In a combined series from seven separate reports of 439 cases of aneurysmal bone cyst only $12(2.7 \%)$ were primary rib lesions. $^{3-9}$

Primary rib tumours are themselves uncommon. The combination of an aneurysmal bone cyst occurring as a primary rib tumour is unusual..$^{10}$ Only 37 cases have been previously described in published reports worldwide. Because of the rarity of this condition and the small size of any one series, we decided to analyse the clinical features of all documented cases in reports published in English and to present four cases of our own.

\section{Case reports}

\section{CASE 1}

A 30 year old woman presented with a six month history of pain and swelling on the right side of her chest. There was a history of trauma to her chest three years previously. On physical examination a 5 $\mathrm{cm} \times 2 \mathrm{~cm}$ non-tender mass was palpable in the

Address for reprint requests: Dr S Sabanathan, Department of Thoracic Surgery, City Hospital, Nottingham NG5 1PD.

Accepted 24 October 1983 mid-axillary line. The findings from the remainder of the physical examination and all laboratory investigations were normal. A chest radiograph showed a fusiform lytic lesion in the right sixth rib. The mass and the adjacent segments of the fifth and seventh ribs were resected en bloc. Her postoperative progress was uneventful and she has remained well without recurrence for nine years. Microscopically the diagnosis of an aneurysmal bone cyst was established.

\section{CASE 2}

A man of 60 years was sent to our department after a routine chest radiograph showed an expanding lesion in the anterior third of the left ninth rib. Except for mild tenderness over the area, the physical findings and laboratory values were all within normal limits. A mass was neither visible nor palpable. The ninth rib was explored through a standard left posterolateral thoracotomy, where a cystic mass was found in the anterior half of the ninth rib. En bloc excision was undertaken; this included normal rib and periosteum at either end, the underlying adherent parietal pleura, and adjacent intercostal muscles and bundles. The patient was discharged on the ninth postoperative day after an uneventful recovery. He has been followed up for six years and there is no sign of recurrence. Microscopic examination confirmed the diagnosis of aneurysmal bone cyst.

\section{CASE 3}

An 18 year old woman was admitted to hospital for excision of a tumour of the left first rib. The lesion was discovered on a routine chest radiograph. She had been previously well and was symptomless at the time of admission. There was no history of trauma to the chest wall. Physical examination showed nothing abnormal apart from a hard non- 
tender mass felt in the left supraclavicular fossa. Chest radiography (fig 1 ) showed a lesion arising from the ventral two thirds of the left first rib. Through a posterior parascapular approach the entire first rib and tumour were resected en bloc with the second rib. The patient's postoperative course was uneventful and there has been no evidence of recurrence during the 10 months since operation. The pathological diagnosis was aneurysmal bone cyst of the first rib.

\section{CASE 4}

A 51 year old man was first seen at Nottingham City Hospital in November 1972, having been referred because of an abnormal chest radiograph. This showed a mass located along the axis of the left sixth rib close to the posterior angle (fig $2 a$ ). The cortex overlying this lesion was intact. The lesion was considered to be a benign bone cyst and no treatment was believed necessary. When the patient was recalled for a chest radiograph in 1983, the rib lesion had increased in size and had become painful (fig $2 b$ ). Hence we decided to excise it. The mass and the adjacent segment of the fifth and seventh ribs were resected en bloc. Recovery was uneventful and at follow up three months later the patient was doing well. The final pathological diagnosis was aneurysmal bone cyst.

\section{Discussion}

\section{CLINICAL FEATURES}

The 37 cases of aneurysmal bone cysts of the rib that have been reported worldwide are summarised in the table. On the basis of our four cases in conjunc-

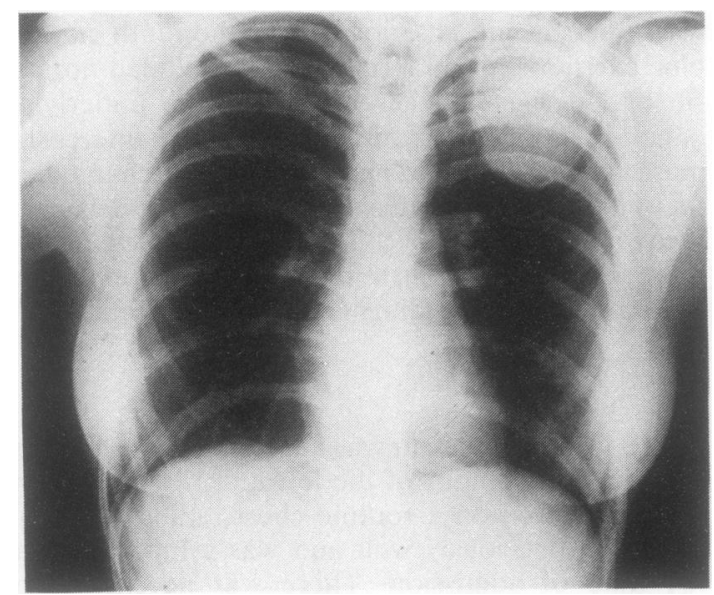

Fig 1 Case 3: Chest radiograph showing an aneurysmal bone cyst of the left first rib.

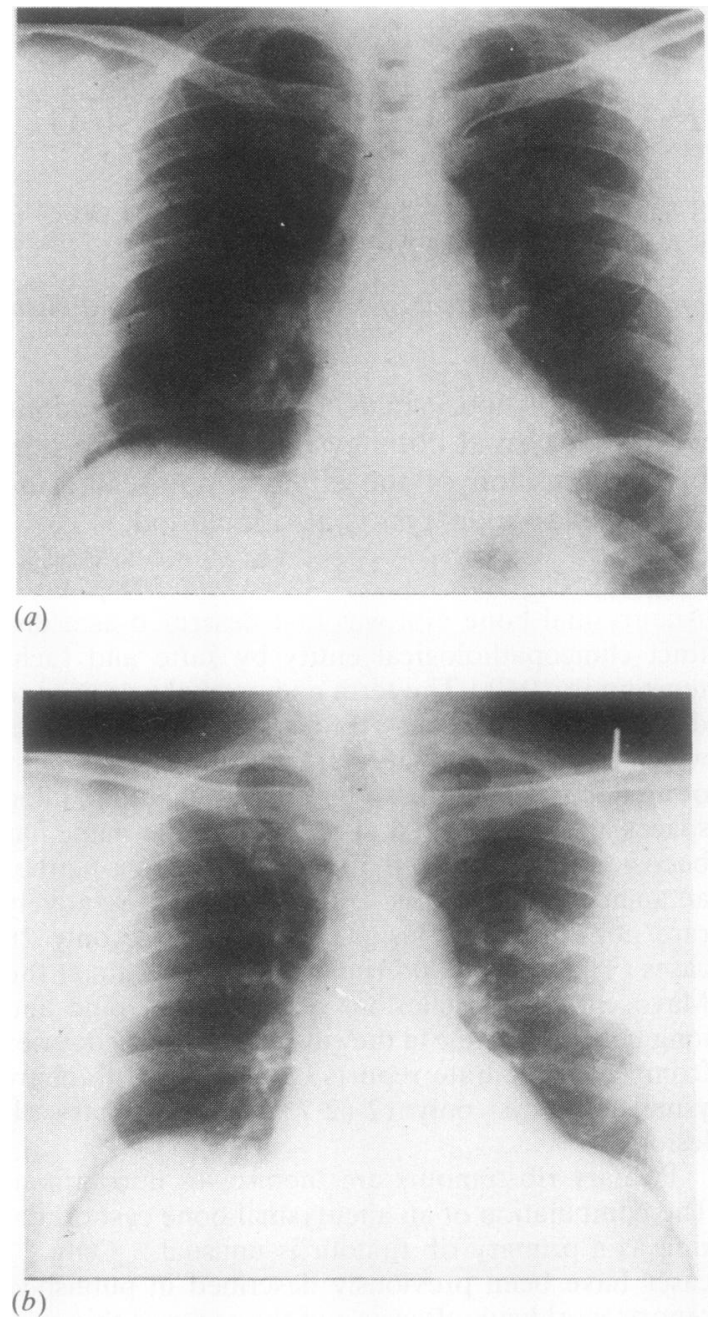

Fig 2 Case 4: Chest radiographs showing an aneurysmal bone cyst of the left sixth rib (a) in 1972 and $(b)$ in 1983.

tion with the 24 cases from published reports for which there is adequate information, the usual modes of presentation are pain $(46 \%)$, incidental finding at routine chest radiography $(29 \%)$, palpable lump (21\%), dyspnoea (7\%), paraplegia (7\%), and pathological fracture $(7 \%)$. The ages range from newborn to 68 years, with an average age of : 22.8 years. Aneurysmal bone cyst is primarily, however, a condition of the second and third decades, ${ }^{4-7}$ although cases do occur in later life. There was a slightly but not significantly higher female incidence. Aneurysmal bone cysts have been described in every rib except the lower three. 
Summary of published cases of aneurysmal bone cysts of ribs

\begin{tabular}{|c|c|c|c|c|c|c|c|}
\hline Reference & $A g e^{*}$ & Sex & $\begin{array}{l}\text { Location } \\
\text { of lesion }\end{array}$ & $\begin{array}{l}\text { Presenting } \\
\text { complaint }\end{array}$ & Treatment & Results $\dagger$ & Recurrence \\
\hline Pascuzzi et al ${ }^{10}$ & 24 & $\mathrm{~F}$ & R 7th rib & & $\begin{array}{l}\text { Total } \\
\text { excision }\end{array}$ & $\begin{array}{l}\text { Full } \\
\text { recovery }(8 \text { y) }\end{array}$ & No \\
\hline $\begin{array}{l}\text { Bossart and } \\
\text { Fitzpatrick" }\end{array}$ & 30 & $\mathbf{F}$ & R 4th rib & $\begin{array}{l}\text { R chest pain, } \\
\text { pathological } \\
\text { fracture of rib }\end{array}$ & $\begin{array}{l}\text { Total } \\
\text { excision }\end{array}$ & $\begin{array}{l}\text { Full } \\
\text { recovery }(4 \text { y) }\end{array}$ & No \\
\hline \multirow[t]{2}{*}{ Bowles et al ${ }^{12}$} & 31 & $\mathbf{F}$ & L 2nd rib & Pain & $\begin{array}{l}\text { Total } \\
\text { excision }\end{array}$ & & \\
\hline & 33 & $\mathbf{F}$ & L 5th rib & Pain & $\begin{array}{l}\text { Total } \\
\text { excision }\end{array}$ & & \\
\hline \multirow[t]{2}{*}{ Robinson et al ${ }^{13}$} & 22 & $\mathbf{M}$ & R 4th rib & $\begin{array}{l}\text { Pain, weakness } \\
\text { of } R \text { lower } \\
\text { limb, sensory } \\
\text { loss in both } \\
\text { lower limbs }\end{array}$ & $\begin{array}{l}\text { Total } \\
\text { excision of } \\
\text { rib, lamin- } \\
\text { ectomy }\end{array}$ & $\begin{array}{l}\text { Full } \\
\text { recovery (6 m) }\end{array}$ & No \\
\hline & 68 & $\mathbf{M}$ & R 8th rib & $\begin{array}{l}\text { Pain in chest, } \\
\text { pathological } \\
\text { fracture of rib }\end{array}$ & $\begin{array}{l}\text { Total } \\
\text { excision }\end{array}$ & & \\
\hline \multirow[t]{2}{*}{ Bridger $^{14}$} & 59 & $\mathbf{F}$ & $\begin{array}{l}\mathrm{R} 7 \text { th and } \\
\text { 8th ribs }\end{array}$ & $\begin{array}{l}\text { Abnormal chest } \\
\text { radiograph }\end{array}$ & $\begin{array}{l}\text { Curettage, } \\
\text { Radiotherapy }\end{array}$ & $\begin{array}{l}\text { Full } \\
\text { recovery }(2 y)\end{array}$ & No \\
\hline & 16 & $\mathbf{M}$ & L 5th rib & Tender lump & $\begin{array}{l}\text { Total } \\
\text { excision }\end{array}$ & $\begin{array}{l}\text { Full } \\
\text { recovery ( } 3 \text { y) }\end{array}$ & No \\
\hline Slowick $e t a l^{9}$ & 18 & $\mathbf{M}$ & 5th rib & Lump & $\begin{array}{l}\text { Total } \\
\text { excision }\end{array}$ & $\begin{array}{l}\text { Full } \\
\text { recovery ( } 2 \text { y) }\end{array}$ & No \\
\hline Sandozi et al ${ }^{15}$ & $\begin{array}{l}\text { Middle } \\
\text { aged }\end{array}$ & $\mathrm{F}$ & R 6th rib & Dyspnoea & Biopsy & Died & No \\
\hline $\begin{array}{r}\text { Henley and } \\
\text { Ricketts }^{16}\end{array}$ & 52 & $\mathbf{F}$ & L 6th rib & $L$ chest pain & $\begin{array}{l}\text { Partial } \\
\text { excision }\end{array}$ & $\begin{array}{l}\text { Dyspnoea } \\
\left(4^{1 / 2} \text { y) }\right.\end{array}$ & Yes \\
\hline $\begin{array}{l}\text { Dabska and } \\
\text { Buraczewskit }\end{array}$ & 28 & $\mathbf{F}$ & $\begin{array}{l}R \text { 3rd rib } \\
\text { eroding into D3 }\end{array}$ & Chest pain & $\begin{array}{l}\text { Excision } \\
\text { of rib }\end{array}$ & $\begin{array}{l}\text { Full } \\
\text { recovery }(12 \text { y) }\end{array}$ & No \\
\hline $\begin{array}{l}\text { Joseph and } \\
\text { Fonkalsrun }^{17}\end{array}$ & $5 \mathrm{~m}$ & $\mathbf{M}$ & L 9th rib & Lump & $\begin{array}{l}\text { Total } \\
\text { excision }\end{array}$ & $\begin{array}{l}\text { Full } \\
\text { recovery }(15 \mathrm{~m})\end{array}$ & No \\
\hline Anjaria et al ${ }^{18}$ & 17 & $\mathbf{F}$ & R 8th rib & Paraplegia & $\begin{array}{l}\text { Excision of rib, } \\
\text { curettage of } \\
\text { vertebral } \\
\text { extension }\end{array}$ & $\begin{array}{l}\text { Full } \\
\text { recovery (6 m) }\end{array}$ & No \\
\hline Koskinen $e t a l^{3}$ & $\begin{array}{l}\text { Not } \\
\text { stated }\end{array}$ & $\begin{array}{l}\text { Not } \\
\text { stated }\end{array}$ & 5th rib & Pain & $\begin{array}{l}\text { Total } \\
\text { excision }\end{array}$ & $\begin{array}{l}\text { Full } \\
\text { recovery (4 y) }\end{array}$ & No \\
\hline Hurvitz et al ${ }^{19}$ & 14 & $\mathbf{M}$ & R 8th rib & Chest pain & $\begin{array}{l}\text { Biopsy, } \\
\text { total } \\
\text { excision }\end{array}$ & $\begin{array}{l}\text { Full } \\
\text { recovery }\end{array}$ & No \\
\hline Watanabe $^{20}$ & 20 & $\mathrm{~F}$ & L 9th rib & $\begin{array}{l}\text { Abnormal chest } \\
\text { radiograph }\end{array}$ & $\begin{array}{l}\text { Total } \\
\text { excision }\end{array}$ & $\begin{array}{l}\text { Full } \\
\text { recovery }\end{array}$ & No \\
\hline $\begin{array}{l}\text { Deluccia and } \\
\text { Reyes }^{21}\end{array}$ & 43 & $\mathrm{~F}$ & L 6th rib & $\begin{array}{l}\text { Abnormal chest } \\
\text { radiograph }\end{array}$ & $\begin{array}{l}\text { Total } \\
\text { excision }\end{array}$ & $\begin{array}{l}\text { Full } \\
\text { recovery }\end{array}$ & \\
\hline Kushner et al ${ }^{22}$ & 13 & $\mathbf{M}$ & $\begin{array}{l}\mathrm{R} 3 \mathrm{rd} \text { and } \\
\text { 4th ribs }\end{array}$ & $\begin{array}{l}\text { Pain, swelling } \\
\text { in right axilla }\end{array}$ & $\begin{array}{l}\text { Total } \\
\text { excision }\end{array}$ & $\begin{array}{l}\text { Full } \\
\text { recovery }\end{array}$ & \\
\hline \multirow[t]{3}{*}{$\begin{array}{l}\text { McCarthy and } \\
\text { Dorfman }^{23}\end{array}$} & $7 \mathrm{~m}$ & $\mathbf{M}$ & R 9th rib & Dyspnoea & $\begin{array}{l}\text { Total } \\
\text { excision }\end{array}$ & $\begin{array}{l}\text { Full } \\
\text { recovery (4 m) }\end{array}$ & No \\
\hline & $4 \mathrm{~m}$ & $\mathbf{M}$ & L 4th rib & $\begin{array}{l}\text { Abnormal chest } \\
\text { radiograph }\end{array}$ & $\begin{array}{l}\text { Total } \\
\text { excision }\end{array}$ & $\begin{array}{l}\text { Full } \\
\text { recovery }\end{array}$ & No \\
\hline & Newborn & $\mathbf{M}$ & $\begin{array}{l}\mathrm{R} 7 \text { th and } \\
\text { 8th ribs }\end{array}$ & Lump & $\begin{array}{l}\text { Total } \\
\text { excision }\end{array}$ & $\begin{array}{l}\text { Full } \\
\text { recovery }\left(1 \frac{1}{2} \text { y) }\right.\end{array}$ & No \\
\hline Lichtenstein ${ }^{24}$ & \multicolumn{2}{|c|}{ ( 2 cases) } & Not stated & & & & \\
\hline Ishinada et $a l^{25}$ & \multicolumn{2}{|c|}{ ( 4 cases) } & Not stated & & & & \\
\hline Tillman $e t a l$ & \multicolumn{2}{|c|}{ ( 2 cases) } & & $\begin{array}{l}\text { Abnormal chest } \\
\text { radiograph }\end{array}$ & $\begin{array}{l}\text { Total } \\
\text { excision }\end{array}$ & & \\
\hline Campanacci et alo & \multicolumn{2}{|c|}{ ( 2 cases) } & Not stated & & & & \\
\hline Ruiter $e t a l^{\mathbf{s}}$ & \multicolumn{2}{|c|}{ ( 4 cases) } & Not stated & & & & \\
\hline Ochsner et $a l^{26}$ & \multicolumn{2}{|c|}{ Not stated } & Not stated & & & & \\
\hline
\end{tabular}

*Years unless otherwise stated.

†Follow up in parentheses 


\section{RADIOLOGICAL FEATURES}

The radiographic features of an aneurysmal bone cyst vary with the maturity and location of the lesion. The typical appearance is that of an eccentric, lytic "blowout" type of lesion, sharply demarcated by a thin shell of subperiosteal new bone (fig 1). A mottled calcification occurs in the fibrosseous septa lining the vascular spaces and imparts a soap bubble or honeycomb appearance. As the cyst grows the outer shell and osseous trabeculae become more dense and the lesion more calcified (fig 2). Dabska and Buraczewski ${ }^{4}$ and Sherman and Soong ${ }^{27}$ contend that there are four stages of the aneurysmal bone cyst. The initial stage is characterised by osteolysis of margins with periosteal elevation. The second stage is the stage of growth, sometimes rapid, showing progressive destruction of bone and poor demarcation. The third stage is the phase of stabilisation showing the characteristic radiographic features of the bony shell and osseous septae. The fourth stage is the healing phase showing ossification and formation of a bony mass. Sherman and Soong reported that three of 17 cases reached this late stage without treatment, even though they had no biopsy material from these lesions. Lichtenstein ${ }^{24}$ believed that an aneurysmal bone cyst will not enter the fourth stage without radiotherapy. Most lesions present in the third stage.

\section{PATHOLOGY}

Grossly the lesion consists of pools of blood in cavities delineated by walls of variable thickness (fig 3). Solid areas may be present and may predominate. ${ }^{7}$ The aneurysmal bone cyst replaces the normal bone structure and expands the bone. There is a sometimes incomplete thin rim of reactive new bone beneath the raised periosteum. The walls of the spaces often contain bone or chondroid tissue. Giant cells in the solid areas may make differentiation from giant cell tumour difficult. Differentiation from a unicameral bone cyst may be impossible, particularly with curetted material. ${ }^{4}$

Ultrastructural studies showed fibroblasts to be the most frequent cell ${ }^{28}$; in addition, there were histiocytes, poorly differentiated monocytoid cells, and primitive mesenchymal cells. ${ }^{28}$ Osteoclast like features were seen in the multinucleate giant cells. A specialised endothelial lining was not identified, the flattened cells resembling fibroblasts. The spaces were mostly lined by fibrin covered collagen. The ultrastructure features are in keeping with the theory that aneurysmal bone cysts are reactive lesions.

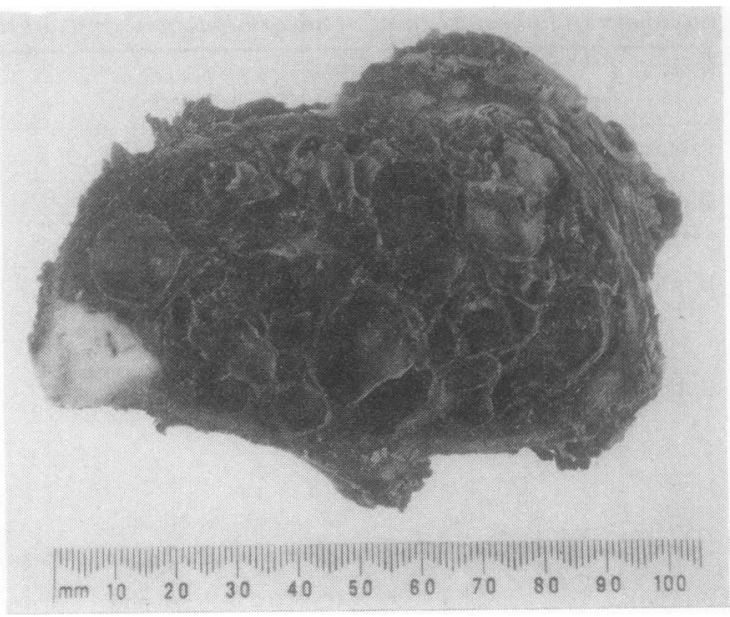

Fig 3 Case 3: Multiple blood filled cysts, with smooth linings, eccentrically expanding the rib.

\section{AETIOLOGY AND PATHOGENESIS}

The aetiology of an aneurysmal bone cyst is unknown, but circulatory disturbance is widely accepted as a factor in its pathogenesis. ${ }^{1830}$ Such a change might occur as a primary lesion in otherwise normal bone ${ }^{1}$ or be a secondary feature grafted on a pre-existing bone lesion and replacing it to a greater or lesser extent. ${ }^{31}$ Trauma and haemorrhage have been implicated, where the resulting haematoma undergoes liquefaction and organisation and eventually becomes cystic. ${ }^{32}$ Although attractive, this theory fails to explain many non-traumatic examples of this lesion and the rarity of aneurysmal bone cyst by comparison with the common occurrence of trauma. Areas resembling aneurysmal bone cyst may be seen in giant cell tumours, chondroblastomas, chondromyxoid fibromas, fibrous dysplasia, and malignant tumours. ${ }^{583334}$ These bone lesions may form only a small focus within the cyst. ${ }^{8}$ Hence the pathologist must have an adequate biopsy specimen or he may find it difficult to distinguish the aneurysmal bone cyst from an associated bone lesion, ${ }^{1434}$ particularly a malignant neoplasm. ${ }^{22}$ It seems reasonable that local haemodynamics are altered in the region of these bone tumours. Tillman et al, ${ }^{7}$ however, were unable to find any associated neoplasm in 95 cases, despite careful scrutiny.

The natural history of these cysts is not known. There have been reports of spontaneous regression ${ }^{27}$ and cure after biopsy alone.35 Godfrey and Gresham $^{36}$ took this idea and developed it as a result of their study of six cysts found at different ages, including two undetected until necropsy. They suggested a natural history of onset in childhood, with a 
period of active growth followed-in those cysts remaining undetected to an inactive stage-by thrombosis and fibrosis. These reports have, however, been regarded as misleading since they have not been substantiated by sufficient clinical, radiographic, and microscopic evidence. ${ }^{37}$ Persistence and growth of the lesion in one of our patients (case 4) supports the view of Lichtenstein ${ }^{24}$ that these cysts will not regress without treatment.

\section{TREATMENT}

There is general agreement that aneurysmal bone cysts are benign. ${ }^{30}$ Although the cyst is not a true neoplasm, local extension can cause paralysis ${ }^{1318}$ and incomplete removal can result in persistence and growth of the lesion. ${ }^{2430}$ Because of the potential for bone destruction and rapid growth shown by some of these cysts, Lichtenstein ${ }^{24}$ strongly recommended that once the lesion is discovered treatment should be instituted as soon as possible.

The treatment of choice is complete local excision when it is feasible. In all the series studied ${ }^{4-9}$ there were no recurrences after total excision. Curettage of the lesion, though effective, results in a higher frequency of recurrence. ${ }^{5830}$ Biesecker et al ${ }^{8}$ reported a low recurrence rate with cryosurgery. Although the series of patients treated with this method is small, the results are promising.

Irradiation should be considered only when surgical access is difficult or impossible ${ }^{30}$ Extreme caution, however, should be exercised with this mode of treatment as there is always the possibility of damage to physis or the late development of sarcoma. Tillman et $\mathrm{al}^{7}$ and Aho et $\mathrm{al}^{29}$ reported that sarcoma developed in aneurysmal bone cysts that had been treated with irradiation. Dabska and Buraczewski ${ }^{4}$ and Lichtenstein ${ }^{24}$ each reported a case of fibrosarcoma after radiation treatment of an aneurysmal bone cyst. Another disadvantage is that aneurysmal bone cysts do not decrease in size after" radiotherapy.

\section{COMMENT}

Primary neoplasms of the ribs are uncommon. As reported in published papers, they comprise 5-7\% of all primary bone tumours. ${ }^{102638}$ Malignant tumours are significantly more common than benign tumours in this location. ${ }^{2629}$ Most malignant neoplasms of the rib are metastatic. ${ }^{263940}$ Primary rib tumours are as frequently benign as they are malignant. ${ }^{102639}$

To establish the diagnosis of a primary neoplasm of the rib it is necessary first to exclude a metastatic deposit or a local extension or manifestation of a separate disease. When these are ruled out the differentiation between benign and malignant primary growth still remains inconclusive. ${ }^{10263840}$ No conclusion about the nature of the tumour can be drawn from the symptoms or their duration or from the age of the patient, ${ }^{10264041}$ unless the lesion has declared itself malignant by local or distant spread. Differentiation between benign and malignant rib tumours is not possible by radiographic criteria, unless cortical destruction and involvement of soft tissues are found. ${ }^{3941}$ Tumour confined to a single rib does not necessarily imply a benign process as malignant tumours may also be confined to one rib at their inception. ${ }^{39}$ These lesions should therefore always be treated as potentially malignant. ${ }^{102638-41}$

Just as the nature of the tumour often cannot be determined from the clinical and radiographic features, sometimes even skilled pathologists find it difficult to predict its biological behaviour on the basis of histological examination. ${ }^{263941}$ Hence wide excision is necessary not only for adequate diagnosis but also to provide the best chance of a cure in both benign and malignant lesions. Wide excision of rib tumours should include the rib above and below, the adjacent muscles, and underlying pleura. As much of the diseased rib as possible should be excised because of the great tendency for intramarrow and periosteal extension. ${ }^{4142}$ Entire removal, particularly of the first rib, for malignancy affecting any portion of it is advocated by Fort ${ }^{43}$ since partial resection in this extremely vascular area is frequently followed by early infiltration and general metastases. A large tumour is no contraindication to radical removal. ${ }^{41}$ Large segments of the chest wall may be removed and reconstructed with little functional disturbance. Various materials have been used to reconstruct chest wall defects including Marlex mesh, ox fascia, methyl methacrylate, metal struts, and autotransplantation of ribs or even diaphragm. ${ }^{26445}$

We are grateful to Dr ID Ansell, consultant pathologist, for his advice and encouragement. Our thanks are also due to Mr W Brakenbury for the illustrations.

\section{References}

' Jaffe HL, Lichtenstein L. Solitary unicameral bone cyst, with emphasis on the Roentgen picture, the pathologic appearance and the pathogenesis. Arch Surg 1942;44:1004-25.

2 Dahlin DC. Bone tumours. 2nd ed. Springfield: Charles C Thomas, 1967:242-5.

${ }^{3}$ Koskinen EVS, Visuri TI, Holmstrom T, Roukkula MA. Aneurysmal bone cyst: evaluation of resection and of curettage in 20 cases. Clin Orthop 1976;118: 136-46.

${ }^{4}$ Dabska M, Buraczewski J. Aneurysmal bone cyst: pathology, clinical course and radiologic appearance. Cancer 1969;23:371-89. 
${ }^{5}$ Ruiter DJ, Van Rijssel TG, Van der Velde EA. Aneurysmal bone cysts: a clinicopathological study of 105 cases. Cancer 1977;39:2231-9.

- Campanacci M, Cervellati C, Donti U, Bertoni F. Aneurysmal bone cyst (a study of 127 cases, 72 with longterm follow up). Ital $J$ Orthop Traumatol 1976;2:341-53.

7 Tillman BP, Dahlin DC, Lipscomb PR, Stewart JR. Aneurysmal bone cyst: an analysis of ninety five cases. Mayo Clin Proc 1968;43:478-95.

${ }^{8}$ Biesecker JL, Marcove RC, Huvos AG, Mike V. Aneurysmal bone cysts: a clinicopathologic study of 66 cases. Cancer 1970;26:615-25.

${ }^{9}$ Slowick FA, Campbell CJ, Kettelkamp DB. Aneurysmal bone cyst: an analysis of thirteen cases. J Bone Joint Surg 1968;50A:1142-51.

${ }^{10}$ Pascuzzi CA, Dahlin DC, Clagett OT. Primary tumours of the ribs and sternum. Surg Gynecol Obstet 1957;104:390-400.

" Bossart PA, Fitzpatrick HF. Aneurysmal bone cyst of rib: differential diagnosis and treatment. Arch Surg 1964;88:229-32.

${ }^{12}$ Bowles LT, Corn RL, Miscall L. Aneurysmal bone cyst of the rib. NY State J Med 1965;65:298-9.

${ }^{13}$ Robinson AE, Thomas RL, Monson DM. Aneurysmal bone cyst of the rib: a report of two unusual cases. $A m$ J Roentgenol 1967;100:526-9.

${ }^{14}$ Bridger P. Aneurysmal bone cyst: difficulties in diagnosis. Aust NZ J Surg 1967;36:212-7.

is Sandozi MK, Vittal Rao KR, Ram Das V, Lingam R. Aneurysmal bone cyst of the rib. J Indian Med Ass 1968;51:293-4.

${ }^{16}$ Henley FT, Ricketts GL. Aneurysmal bone cyst presenting as a chest mass: a case report. Radiology 1969;92: $1103-4$

${ }^{17}$ Joseph WL, Fonkalsrud EW. Primary rib tumours in children. Am Surg 1972;38:338-42.

18 Anjaria PD, Patel DC, Yodh SB. Paraplegia due to aneurysmal bone cyst of rib: a case report. J Postgrad Med 1973;19:185-7.

${ }^{19}$ Hurvitz JS, Harrison MR, Weitzman JJ. Aneurysmal bone cyst mimicking Ewing's sarcoma of the rib. $J$ Pediatr Surg 1977;12: 1067-9.

${ }^{20}$ Watanabe R. Solitary bone cyst of the rib. Arch Jap Chir 1977;46:68-71.

${ }^{21}$ Deluccia VC, Reyes EC. Aneurysmal cyst of the rib. $N Y$ State J Med 1982;82:1077-9.

${ }^{22}$ Kushner DC, Vance Z, Kirkpatrick JA jun. Case report 103. Skeletal Radiology 1979;4:240-3.

${ }^{23}$ McCarthy EF, Dorfman HD. Vascular and cartilaginous hamartoma of the ribs in infancy with secondary aneurysmal bone cyst formation. Am J Surg Pathol 1980;4:247-53.

${ }^{24}$ Lichtenstein L. Aneurysmal bone cyst: observation in 50 cases. J Bone Joint Surg 1957;39A:873-82.

${ }^{25}$ Ishinada $Y$, Yabe $H$, Ogoshi E, Nishikawa K, Iri $\mathbf{H}$. Aneurysmal bone cyst of the sternum. Ann Thoracic
Surg 1979;27:254-9.

${ }^{26}$ Ochsner A jun, Lucas GL, McFarland GB jun. Tumours of the thoracic skeleton: review of 134 cases. J Thorac Cardiovasc Surg 1966;52:311-21.

${ }^{27}$ Sherman RS, Soong KY. Aneurysmal bone cyst: its roentgen diagnosis. Radiology 1957;68:54-64.

${ }^{28}$ Steiner GC, Kantor EB. Ultrastructure of aneurysmal bone cyst. Cancer 1977;40:2967-78.

${ }^{29}$ Aho HJ, Aho AJ, Einola S. Aneurysmal bone cyst. A study of ultrastructure and malignant transformation. Virchows Arch (Pathol Anat) 1982;395:169-79.

${ }^{30}$ Clough JR, Price CHG. Aneurysmal bone cyst: pathogenesis and long term results of treatment. Clin Ortho 1973;97:52-63.

${ }^{31}$ Jaffe HL. Aneurysmal bone cyst. Bull Hosp Joint Dis 1950;11:3-13.

${ }^{32}$ Aegerter EE, Kirkpatrick JA. Orthopaedic diseases: physiology, pathology, radiology. 4th ed. Philadelphia: WE Saunders, 1975:424.

${ }^{33}$ Buraczewski J, Dabska M. Pathogenesis of aneurysma bone cyst: relationship between the aneurysmal bone cyst and fibrous dysplasia of bone. Cancer 1971;28:597-604.

${ }^{34}$ Banakdarpour A, Levy WM, Aegerter E. Primary and secondary aneurysmal bone cysts: a radiological study of 75 cases. Radiology 1978;126:75-83.

${ }^{35}$ Murray RO, Jacobson JG. Radiology of skeletal disorders. London: Churchill Livingstone, 1971:382-6, 946-9.

${ }^{36}$ Godfrey LW, Gresham GA. The natural history of aneurysmal bone cyst. Proc $R$ Soc Med 1959; 52:900-5.

${ }^{37}$ McNamara G, Beheshti F, Saunders TG, Glubo SM. Aneurysmal bone cyst of a metatarsal: a case report and review of the literature. Journal of the American Podiatry Association 1982;72:356-60.

${ }^{38}$ Teitelbaum SL. Twenty years' experience with intrinsic tumours of the bony thorax at a large institution. $J$ Thorac Cardiovasc Surg 1972;63:776-82.

${ }^{39}$ Hochberg LA, Crastnopol P. Tumours of the ribs. Dis Chest 1955;28:406-15.

${ }^{40}$ Teitelbaum SL. Tumours of the chest wall. Surg Gynecol Obstet 1969;129:1059-73.

${ }^{41}$ Barrett NR. Primary tumours of rib. $\mathrm{Br} J$ Surg 1955;43:113-32.

${ }^{42}$ Upshaw JE, Mcdonald JR, Ghormley RK. Extension of primary neoplasms of bone to bone marrow. Surg Gynec Obstet 1949;89:704-14.

${ }^{43}$ Fort RE. Excision of the clavicle and first rib for malig- $\frac{T}{9}$ nant disease. Surg Gynec Obstet 1914;18:696-8.

44 Burnard RJ, Martini N, Beattie EJ. The value of resection in tumours involving the chest wall. $J$ Thorac Cardiovasc Surg 1974;68:530-5.

${ }^{45}$ Ramming KP. Holmes EC, Zarem HA, Lesavoy MA, N Morton DL. Surgical management and reconstruction of extensive chest wall malignancies. Am J Surg 1982;144:146-52. 